\section{EMBRYRIDDLE Aeronautical University}

SCHOLARLY COMMONS
International Journal of Aviation, Aeronautics, and Aerospace

\title{
As Assessment of Airline Service Quality in a Category One Nation: Focus on Mallam Aminu Kano International Airport
}

Obioma R. Nwaogbe

Department of Transport Management, Federal University of Technology, Minna., obioma.nwaogbe@futminna.edu.ng

Abraham Pius

Manchester Metropolitan University UK, abraham.pius@stu.mmu.ac.uk

A. O. Balogun

Federal University of Technology, Minna, fmjjasper@gmail.com

C. C. Ikeogu

Federal University of Technology, Owerri, krisiikegu@gmail.com

V. Omoke

Federal University of Technology, Minna, victor.omoke@futminna.edu.ng

Follow this and additional works at: https://commons.erau.edu/ijaaa

\section{Scholarly Commons Citation}

Nwaogbe, O. R., Pius, A., Balogun, A. O., Ikeogu, C. C., \& Omoke, V. (2017). As Assessment of Airline Service Quality in a Category One Nation: Focus on Mallam Aminu Kano International Airport. International Journal of Aviation, Aeronautics, and Aerospace, 4(1). https://doi.org/10.15394/ ijaaa.2017.1157

This Article is brought to you for free and open access by the Journals at Scholarly Commons. It has been accepted for inclusion in International Journal of Aviation, Aeronautics, and Aerospace by an authorized administrator of Scholarly Commons. For more information, please contact commons@erau.edu. 
The aviation industry plays a major role in the aspect of work and leisure to people around the globe. It improves economic growth and helps in poverty alleviation by providing employment opportunities and increasing revenues from taxes (Nwaogbe et al., 2013). Service industry managers are under tremendous pressure to prove their services are customers oriented and there is room for improvement of performance that guarantees competitive advantage to the marketplace (Rhoades \& Waguespack, 2008; 2004). As Griffin (2008) suggests customers who are satisfied with the product or service purchased will likely come back for more business, compare to those customers whom their expectations were not met.

Assessing performance in the service industry, without defining key "constants" would be a trivial pursuit, especially in the airline sector (Garvin, 2010 $\&$ Chen, 2008). While Lopes et al., (2007) believe that service quality in the airline industry is monitored and widely discussed, carriers with low performance are criticized publicly by the stakeholders. The challenges face the aviation industry to offer appropriate service attributes to the passengers, thus what constitute service attributes remains a subject for debate. These attributes can be difficult to define from the passengers' perspective (Park et al., $2004 \&$ Chang et al., 2002).

\section{Study Background}

This study considers airline quality from the customer's perception at a CAT 1 state. A nation that complies with the International Civil Aviation Organisation (ICAO) standards. The country whose civil aviation authority is assessed by the Federal Airport Administration (FAA) inspectors, and considered to license and oversee its air carriers and airports satisfactorily as required by the ICAO. Recent growth in aviation investment propels the development of airline and airport industries, and strategically positioning the sector for domestic and international competitive edge. Consequently, it is important for stakeholders (passengers, investors, and governments), to establish the relationship between airlines' quality of service and passenger's perspectives on comfort, affordability, and reliability at the KAN.

\section{Study Rationale}

This study is among the very few to consider airline quality of service in CAT 1 nations. Very little knowledge exists in this field - although previous studies on service quality have largely ignored developing sub-Saharan region and literature involving aviation management of quality is scarce within academia. This area of study aims to provide research into a new intellectual terrain while providing useful 
findings to benefit the aviation sector. This study will play a significant role in determining the standard of service provided by these airlines to the passengers.

\section{Problem Statement}

This study addresses the lack of established research in airlines quality of service at the KAN, and how certification benefits can be maximized by the airlines. Several cross-disciplinary studies suggest that service quality and customer satisfaction judgments involve consumers comparing their expectations to actual service provided by the organization (Wanke et al., 2016 \& Geraldine et al., 2013).

\section{Study Objectives}

This study aims to evaluate airline's quality of service, from air passengers' perspective.

- To assess the relationship between airlines quality of service and passengers' comfort.

- To evaluate the link between service quality and affordability of airlines services.

- To measure the relationship between quality of service and reliability of services.

- To make recommendations for airlines and Government on the way forward.

\section{Study Hypothesis}

- H1: There is no statistically significant relationship between passenger's perspectives and comfortability of service in airline operation at the airport.

- H2: There is no statistically significant relationship between passenger's perspectives and affordability of service in the airline's operation at the airport.

- H3: There is no statistically significant relationship between passenger's perspectives and reliability of service in the airline's operation at this airport.

\section{Study Limitations}

The researchers encountered the following problems; Airlines and airport were reluctant to release data that would have facilitated and reinforced the field survey data gathered. The perceptions of passengers are limited only to one airport KAN and three airlines; Arik Air, Aero, and Azman studied.

\section{Literature Review}

Delivering the highest possible quality of service is regarded as one of the core business requirements that businesses must achieve to attract and retain 
customers, while assessing and embed passengers' views into organisational framework for better customer experience (Nwaogbe, et al., 2013). Customers' oriented policy and practice stand in the vanguard of success and organization existence in a competitive business environment like the airline industry. In measuring airline quality of service, SERVQUAL dimension is widely used in the service sector to assess performance from the human perspective. According to Prabaharan et al., (2008) SERVQUAL method is used in measuring organization strengths and weaknesses, focus on tangibility, reliability, responsiveness, assurance, and empathy. Quality means greatness (Garvin, 2010), value (Cronin \& Taylor, 2011), or "organization that surpasses or meets expectations" (Parasumaran, 1985). The following "constants" will be briefly defined; (comfortability, affordability, and reliability).

Service comfortability - is how passengers observed the quality of service offered to them by the airlines, including; Internet connectivity, lounge's cleanliness, quiet zone, shops, restaurants, and business pavilion in functioning conditions. Airline's communication mediums like staffs, information desk, and inflight announcement are included as tangible features by the passengers (Geraldine et al., 2013).

Service affordability - can be regarded as given passengers the opportunity to select from inclusive air ticket prices made available to the different group of passengers by the airlines, as a gesture of goodwill, to establish and reinforce customer loyalty and repeat purchases essential for business continuity (Benjamin, 2015). Affordable air ticket prices will encourage more passengers to use transport for their domestic traveling.

Service reliability - is the probability that airline will carry out its expected function satisfactorily as stated in the flight schedule (Parasuraman et al., 1985). For instance, passengers expect services on time and schedule. Airlines are dutybound to transport passengers from point $\mathrm{A}$ to $\mathrm{B}$, without any form of delays or cancellations (Wanke et al., 2016).

\section{Assessing Airlines Quality of Service}

Yayla - Kullu \& Tansitpong (2013) believe that measuring airlines' quality of service can be challenging, due to the diversity in service perception and service quality attributes, which are contexts based, selected to reflect the study background. Zhang et al., (2102) airline passengers might receive high technical quality, well-designed and maintained airplanes flown by trained pilots, who are equal to the task. Chou et al., (2011) what passengers' values regarding reliability 
and comfort are helpful and friendly airline staffs, sometimes human judgments can be unclear and difficult to measure using figures. As Chou et al., (2011) noted fuzziness exists for the airlines' service quality, there is no single accepted method for dealing with this issue, as it requires multiple criteria to measure service quality in different contexts. Chou et al., (2011) conducted one of the most far-reaching studies using a set of 28 criteria, adding more six elements. A case study method utilized by the researchers to demonstrate the usefulness of Fuzzy weighted SERVQUAL model.

The study findings revealed that human verdicts were sometimes ambiguous, making it difficult for customers to explain the weights of measurement criteria and satisfaction using precise mathematical figure, as linguistic terms may be more effective in describing the worth. Geraldine et al., (2013) conducted a study into how service attributes, influence airlines cooperate image and passengers' loyalty. SERVQUAL dimension scale was used in a questionnaire designed. Six hundred questionnaires (600) were administered randomly to Arik Air passengers at the Muritala Mohammed Airport (MMA). Factor analysis was used in data analyze, and Pearson correlation coefficient used to find out the link between factored quality dimensions, airline image and passengers loyalty.

The study findings proved that there is a strong statistical link between quality variables, airline image and repeat patronage from the passengers. The study recommended that airline service manager needs to improve service quality, it is one of the strong determinants for cooperate image and repeat patronage. Wahab et al., (2015) carried out a study into passenger satisfaction and retains the loyalty in Malindi airport, focusing on budget carriers in Malaysia. The study design was based on SERVUAL dimensions, two hundred (200) questionnaires were distributed. SPSS, descriptive analysis, Pearson's correlation, multiple regressions were used in data analysis and convenience sampling method. The study findings demonstrated that there is a link between service quality and passenger satisfaction in Malindo airport.

\section{Method}

\section{Research Design}

This study is designed to test the relationship between airline's quality of service and passenger satisfaction, at KAN. Previous research has relied mainly on established airlines companies and airports, largely neglecting these carriers and region, which is the focus of this study. 


\section{Research Approach}

The study follows a positivist philosophy and will, therefore, by necessity follow a deductive process using the quantitative approach. Following an extensive review and consideration of several methods this approach was found to be the most effective, since it would allow the researchers to deal with an observable social reality to produce law-like generalizations'. The philosophy and approach allow the researchers to make use of 'existing theory' to develop a hypothesis and adopt a neutral stance, maintaining a healthy detachment from research, to prevent any chance of influencing the data.

\section{Research Population}

The population of passengers at Kano International Air Terminal is 323,482 . Moreover, their aircraft crew is about 309,360. Arik airline with twentyeight (28) aircraft, the biggest fleet in the country, Aero contractors has thirteen (13) carriers, while Azman airline owned four (4) carriers and the smallest fleet. These carriers were selected, because they are passenger's preferred airlines and level of operation, and considered as the nation's key players within the industry.

\section{Sampling Method}

Convenience sampling technique is the preferred choice, due to availability and the quickness that data need to be obtained. Sampling started on the $25^{\text {th }-} 31^{\text {st }}$ of July, 2016; Time: 7 am to $8 \mathrm{pm}$, passengers were randomly selected while trying to board or disembark Arik Air, Aero Contractor, and Azman airline domestic flights. The random method was used to avoid misrepresentation of participants, and none of the participants was favored than another. This method was used to mitigate the inherent risk that normally associated with lack of cooperation from the passengers. The researchers politely explained study importance to the respondents, as they arrived and departed with the carriers chosen in this study. Only passengers who had acknowledged using these carriers for the past one year were eligible to participate. The researchers administered two hundred (200) questionnaires to the airlines within the designated area which collected one hundred thirty (130) fully completed responses. The survey was conducted over a period than one week.

\section{Data Collection Method}

The study made use of the survey 'questionnaire' for collecting primary data. Since positivism entails the use of the quantitative method for data collection 
to arrive at quantifiable observations. Data was gathered through a survey administered on passengers at KAN, using the domestic terminal. This approach was found to ensure both low costs of resources and efficiency, since it enables replication and data collection from a broad cross-section, due to the similarity of set questions presented.

\section{Data Analysis and Discussion}

To achieve the stated objectives and to test the hypothesis, these techniques included basic descriptive, factor analysis, multiple regression's analysis, and oneway analysis of variance (ANOVA). The hypothesis was also tested using the ANOVA result. Data will be entered Statistical Package for the Social Sciences Windows Version 22.0 (SPSS) program to analyze the findings. A formal coding sheet was designed and used to code all the questions in a systematic way. The formula for multiple regression models is stated as:

$$
\begin{aligned}
& \hat{Y}=b_{0}+b_{1}(x 1)+b_{2}(x 2)+b_{3}(x 3)+\cdots \ldots .+b_{n}(x n)+\mathbf{e}_{n} \\
& \text { Where, } \mathrm{y}=\text { dependent variable } \\
& \boldsymbol{x}_{\boldsymbol{n}}=\text { independent variable } \\
& \boldsymbol{b}_{\mathbf{0}}=\text { constant and } \\
& \boldsymbol{b}_{\boldsymbol{n}}=\text { coefficient of } \mathrm{x} \text {. } \\
& \mathrm{e}_{\mathrm{n}}=\text { error term }
\end{aligned}
$$

Where the dependent variables are: $\mathrm{Y}_{1}=$ Comfortability, $\mathrm{Y}_{2}=$ Affordability and $\mathrm{Y}_{3}=$ Reliability. While the independent variable $x 1, x 2, \ldots \ldots \ldots \ldots n$ are given as follows: Quality of service, Flight delay, Safety challenges, Amount paid, Flight schedule, Airline innovation, Security service, Frequency of flight delay, Frequency of safety challenge.

The above table shows that 80 respondents representing $61.5 \%$ are males while 38.5\% are female's uses Arik, Aero and Azman airlines at Mallam Aminu Kano International Airport. The majority of the passengers using these airlines at KAN domestic terminal are men with $(61.5 \%)$.

The table above shows the age bracket of the respondents, the highest age that uses the airlines are above 35years which have 71 respondents $(54.6 \%)$ of the total population, $13.1 \%$ were $20-30$ years, $24.6 \%$ were $30-35$ years and the lowest age bracket is below 20 years which has a frequency of 10 which is $7.7 \%$ of the population. This means that majority of the passengers traveling with these airlines are 35 years and above. 


\section{Airlines Passengers' Characteristics}

Table 4.1

Gender of Respondents

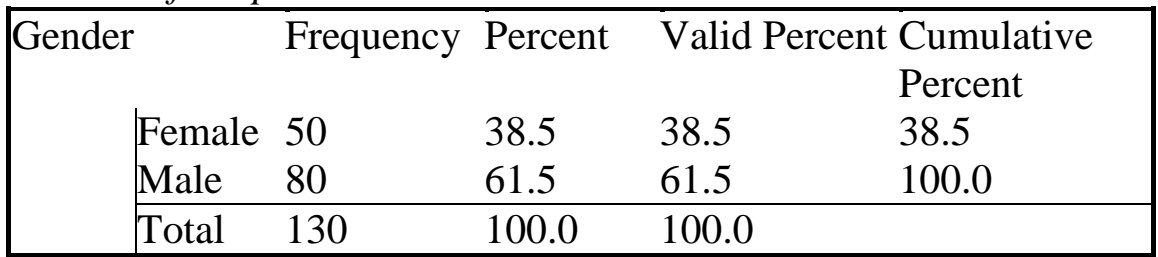

Source: Field Survey (2016)

Table 4.2

Age of Respondents

\begin{tabular}{|lllllll|}
\hline Age & & Frequency & Percent & \multicolumn{2}{c|}{ Valid Percent Cumulative } \\
& & & & & Percent \\
& below 20 & 10 & 7.7 & 7.7 & 7.7 \\
& $20-30$ & 17 & 13.1 & 13.1 & 20.8 \\
Valid & $30-35$ & 32 & 24.6 & 24.6 & 45.4 \\
& 35 above & 71 & 54.6 & 54.6 & 100.0 \\
\cline { 2 - 6 } & Total & 130 & 100.0 & 100.0 & \\
\cline { 2 - 6 } & & & & & \\
\hline
\end{tabular}

Source: Field Survey (2016)

Table 4.3

Occupation of Respondents

\begin{tabular}{|c|c|c|c|c|c|}
\hline \multicolumn{2}{|c|}{ Profession } & Frequency & Percent & \multicolumn{2}{|c|}{ Valid Percent Cumulative } \\
\hline \multirow{6}{*}{ Valid } & Business man/woman & 20 & 15.4 & 15.4 & 15.4 \\
\hline & Politician & 34 & 26.2 & 26.2 & 41.5 \\
\hline & Civil servant & 15 & 11.5 & 11.5 & 53.1 \\
\hline & Others & 56 & 43.1 & 43.1 & 96.2 \\
\hline & Student & 5 & 3.8 & 3.8 & 100.0 \\
\hline & Total & 130 & 100.0 & 100.0 & \\
\hline
\end{tabular}

Source: Field Survey (2016)

The above table shows the status of occupation respondents. Concerning the occupation respondent, 56 respondents $(43.1 \%)$ shows that 'others' has the highest number of respondents. 20 respondents $(15.4 \%)$ were Business men/women, 34 respondents were politicians $(26.2 \%), 15$ respondents were civil servants $(11.5 \%)$, while the occupation with the least number of respondents is students with 5 respondents $(3.8 \%)$. 
Table 4.4

Airlines Patronage

\begin{tabular}{|c|c|c|c|c|}
\hline \multicolumn{2}{|c|}{ Patronage } & Frequency & Percent & $\begin{array}{c}\text { Valid Percent Cumulative } \\
\text { Percent }\end{array}$ \\
\hline \multirow{4}{*}{ Valid } & Arik & 49 & 37.7 & 37.7 \\
\hline & Aero & 41 & 31.5 & 69.2 \\
\hline & Azman & 40 & 30.8 & 100.0 \\
\hline & Total & 130 & 100.0 & 100.0 \\
\hline
\end{tabular}

Source: Field Survey (2016)

The table above shows that $37.7 \%$ of 49 respondents preferred Arik Airline for their domestic traveling from this airport, while $31.5 \%$ of 41 respondents preferred Aero contractor for in-country traveling and $30.8 \%$ of 40 respondents used Azman airline for the same purpose. The result confirms that majority of the passengers (37.7\%) sampled preferred to use Arik Airline for their domestic air travel. Although, the difference is only $6.2 \%$ between Arik and Aero airlines.

Table 4.5

Airlines Flight Schedule

\begin{tabular}{|c|c|c|c|c|c|}
\hline \multirow{2}{*}{\multicolumn{2}{|c|}{ Flight Schedule }} & \multicolumn{3}{|c|}{ Airlines } & Total \\
\hline & & Arik & Aero & Azman & \\
\hline & v.satisfactory & 0 & 4 & 5 & 9 \\
\hline & Satisfactory & 45 & 25 & 35 & 105 \\
\hline & not satisfactory & & 12 & 0 & 16 \\
\hline Total & & 49 & 41 & 40 & 130 \\
\hline
\end{tabular}

Source: Field Survey (2016)

The above table shows that 45 respondents (92\%) of Arik airline passengers reported that the flight schedule is satisfactory, while 4 respondents $(8 \%)$ responded that the service was unsatisfactory. About 4 respondents (9.8\%) of Aero Airline passengers reported that the flight schedule is very satisfactory. While 25 respondents $(61 \%)$ responded that their flight schedule is satisfactory while 12 respondents $(29.3 \%)$ replied that the flight schedule is not satisfactory. 5 respondents (12.5\%) of Azman Airline passengers reported that the flight schedule is very satisfying, while 35 respondents $(87.5 \%)$ indicated that the flight schedule is satisfactory. The result confirms that most passengers $(81 \%)$ are satisfied with the flight schedules of the three airlines. 
Table 4.6

Airlines Flight Delay

\begin{tabular}{|c|c|c|c|c|}
\hline \multirow[t]{2}{*}{ Flight Delay } & & Airlines & & Total \\
\hline & Arik & Aero & Azman & \\
\hline Yes & 20 & 14 & 24 & 58 \\
\hline No & 29 & 27 & 16 & 72 \\
\hline Total & 49 & 41 & 40 & 130 \\
\hline
\end{tabular}

Source: Field Survey (2016)

The above shows that 20 passengers (40.8\%) responded that they experienced flight delays, while 29 passengers (59.2\%) experience no flight delays with Arik airline. Aero airlines 14 passengers (34\%) responded that there were flight delays, while 27 passengers $(66 \%)$ responded that here is no flight delay with Aero airline. Furthermore, 24 responded $(60 \%)$ that there were flight delays with Azman airline, while 16 responded there was no flight delay with Azman airline. Around 58 passengers (44.7\%) experienced flight delays, while 72 passengers $(55.3 \%)$ experienced no delays from these airlines.

Table 4.7

\section{Airlines Security Arrangement}

\begin{tabular}{|c|c|c|c|c|c|}
\hline \multirow{2}{*}{\multicolumn{2}{|c|}{ Security Service }} & \multicolumn{3}{|c|}{ Airlines } & \multirow[t]{2}{*}{ Total } \\
\hline & & Arik & Aero & Azman & \\
\hline & Excellent & 13 & 4 & 2 & 19 \\
\hline & Very good & 8 & 13 & 16 & 37 \\
\hline & Good & 19 & 17 & 21 & 57 \\
\hline & Poor & 9 & 7 & 1 & 17 \\
\hline Total & & 49 & 41 & 40 & 130 \\
\hline
\end{tabular}

Source: Field Survey (2016)

The above table shows that 13 passengers responded (26.5\%) that Arik airline security arrangement at the kiosk is excellent, while 8 passengers responded $(16.3 \%)$ is very good, and 19 passengers responded $(38.8 \%)$ good, while 9 passengers responded (18.4\%) that the security arrangement for the kiosk is poor. For Aero airline, 4 passengers responded $(9.8 \%)$ that the security arrangement excellent, 13 passengers responded (13.7\%) very good, and 17 passengers responded $(41.5 \%)$ good while 7 passengers responded $(17 \%)$ that the security arrangement is poor. For Azman airline, 2 passengers responded (4.9\%) that the security is excellent, 16 passengers responded (40\%) is very good, 21 responded $(51.2 \%)$ good and 1 passenger responded $(2.5 \%)$ that the security service is poor. A total of 30 Arik Airline passengers (23\%) were happy with the security arrangement, while 9 passengers $(6 \%)$ were not happy, Aero Contractor 34 
passengers (26\%) were happy, while 7 passengers (5\%) were not happy. Azman Airlines 39 passengers (30\%) were happy, while only 1 passenger was not happy. The result confirms that majority of the respondents were happy with the airline's security at the kiosk.

Table 4.8

Airlines Safety Measures

\begin{tabular}{|llllll|}
\hline Safety challenges & & \multicolumn{3}{c|}{ Airlines } & Total \\
& & Arik & Aero & Azman & \\
& Yes & 6 & 3 & 25 & 34 \\
& No & 43 & 38 & 15 & 96 \\
\hline Total & & 49 & 41 & 40 & 130 \\
\hline
\end{tabular}

Source: Field Survey (2016)

The above shows that 6 passengers responded (12.2\%) that they have experienced some safety challenges with Arik airline, while 43 passengers responded $(87.8 \%)$ that they have not experienced any safety challenges. For Aero airline, 3 passengers responded $(7.3 \%)$ that they have experienced safety challenges, while 38 passengers responded $(92.7 \%)$ that they have not experienced safety challenges. More so, 25 passengers responded $(62.5 \%)$ that they have experienced safety challenges with Azman airline, while 15 passengers responded $(37.5 \%)$ that they have not experienced safety challenges during their trip. The finding illustrates that majority (74\%) of the passengers were not involved in any safety issue, while (26\%) passengers were engaged in safety issues.

Table 4.9

Airlines Affordability

\begin{tabular}{|lccccr|}
\hline Affordability & & & Airlines & & Total \\
& & Arik & Aero & Azman & \\
& Yes & 46 & 39 & 39 & 124 \\
& No & 3 & 1 & 1 & 5 \\
& Nil & 0 & 1 & 0 & 1 \\
\hline Total & & 49 & 41 & 40 & 130 \\
\hline
\end{tabular}

Source: Field Survey (2016)

The above table shows that 46 passengers responded $(93.9 \%)$ that the prices of Arik airline are affordable, while 3 passengers responded $(6.1 \%)$ that the price is not affordable. Around 39 passengers responded (95.1\%) that Aero airline is affordable, while 1 passenger responded $(2 \%)$ that is not affordable, while 1 passenger $(2 \%)$ did not respond to the question. Around 39 passengers responded $(97.5 \%)$ that Azman airline is affordable, while 1 passenger responded $(2.5 \%)$ that 
it is not affordable. Based on this result, Arik airline with (35\%) is more affordable than two others (Aero and Azman airlines) at this KAN. Around (95\%) of passengers sampled at this airport believed that these airlines are affordable for them. While 5 passengers $(4.1 \%)$ disagreed.

Table 4.10

Airlines Reliability

\begin{tabular}{|lllllr|}
\hline Reliability & & \multicolumn{3}{c|}{ Airlines } & Total \\
& & Arik & Aero & Azman & \\
& Yes & 34 & 31 & 37 & 102 \\
& No & 15 & 9 & 3 & 27 \\
& Nil & 0 & 1 & 0 & 1 \\
\hline Total & & 49 & 41 & 40 & 130 \\
\hline
\end{tabular}

Source: Field Survey (2016)

The above table shows that 34 passengers responded (69.4\%) that Arik airline is a reliable, carrier, while 15 passengers responded $(30.6 \%)$ that the carrier is not reliable. Around 31 passengers (75.6\%) of Aero airline responded that the service is reliable, while 9 passengers $(22 \%)$ responded that the service is not reliable, while 1 passenger $(2.4 \%)$ respondent did not respond to this question. Around 37 respondents (92.5\%) of Azman airline passengers reported that the service is reliable, while 3 respondents $(7.5 \%)$ said the service is not reliable. From the above data Azman airline is the most reliable carrier, then Arik and Aero airlines respectively. The majority (78\%) of the passengers trust these airlines to transport them from point A to B within the country in time, while (20\%) did not trust them to deliver. Although, 1 passenger (2\%) did not respond to the question.

\section{Data Analysis and Hypotheses Testing}

Table 4.11

Regression Analysis for Comfortability Model Summary

\begin{tabular}{|lllll|}
\hline Model R & R Square & $\begin{array}{l}\text { Adjusted } \\
\text { Square }\end{array}$ & $\begin{array}{c}\text { RStd. Error of } \\
\text { the Estimate }\end{array}$ \\
\hline 1 & $.893^{\mathrm{a}}$ & .797 & .782 & .431 \\
\hline
\end{tabular}

a. Predictors: (Constant), Quality of service, Flight delay, Safety measures, Amount paid, Flight schedule, Airline innovation, Security service, Frequency of flight delay, Frequency of safety challenge

From the regression analysis, the total effect of one variable on passenger satisfaction could be direct or indirect effects. The direct effect of an independent 
variable on passenger satisfaction was the unstandardized regression coefficient $(\beta)$ and was considered as the path coefficient for the path model. The indirect effect of an independent variable on the dependent variable through the intervening variable was the total product of the effects of that independent variable on the intervening variables and the effect of the intervening variable on the dependent variable of passenger satisfaction (Preacher \& Hayes, 2008).

Timeliness is also very important to determine the level of passenger satisfaction. The regression analysis of the relationship between $\mathrm{C}(\mathrm{y})-($ comfortability as the dependent variable ) and QS( $\left.\mathrm{x}_{1}\right)$ - ( quality of service ), $\operatorname{FD}\left(\mathrm{x}_{2}\right)$ - ( flight delay), $\mathrm{SC}\left(\mathrm{x}_{3}\right)$ - (safety challenges), $\mathrm{AP}\left(\mathrm{x}_{4}\right)$ - (amount paid), $\mathrm{FS}\left(\mathrm{x}_{5}\right)$ (flight schedule), $\mathrm{AI}\left(\mathrm{x}_{6}\right)$ - (airline innovation), $\mathrm{SS}\left(\mathrm{x}_{7}\right)$ - (security service), $\operatorname{FFD}\left(\mathrm{x}_{8}\right)$ - (frequency of flight delay), $\mathrm{FSC}\left(\mathrm{x}_{9}\right)$ - (frequency of safety challenge), as the independent variable of the quality of service of airline operation in Kano airport was analysed using the Excel software package. From the analyses in table 4.11, the output summary spreadsheet shows that the R-square value is 0.797 , which means that about $80 \%$ of the passengers responded positively strong on the comfortability of service in the airline operations services from the airport based on the explanatory variables $\left(\mathrm{x}_{1}, \mathrm{x}_{2}, \mathrm{x}_{3}, \mathrm{x}_{4}, \mathrm{x}_{5}, \mathrm{x}_{6}, \mathrm{x}_{7}, \mathrm{x}_{8}\right.$ and $\left.\mathrm{x}_{9}\right)$ respectively. The adjusted $\mathrm{R}$ of 0.782 in the output summary shows that about $78 \%$ of the comfortability explained by the explanatory variables. This value is also reasonable and close to the R-square value. Finally, Multiple R shows the overall relationship of the dependent variable comfortability and the independent or explanatory variable $\left(\mathrm{x}_{1}, \mathrm{x}_{2}, \mathrm{x}_{3}, \mathrm{x}_{4}, \mathrm{x}_{5}, \mathrm{x}_{6}, \mathrm{x}_{7}, \mathrm{x}_{8}\right.$, and $\left.\mathrm{x}_{9}\right)$ is about 0.893 , which is approximately $90 \%$.

H1: There is no statistically significant relationship between passenger's perspectives and comfortability of service in airline operation at the airport. Table 4.18, shows that the F value of 129 degrees of freedom is 52.378 and the tabulated value is 0.00 , so therefore alternative hypothesis is accepted since it is less than p-value 0.05 , which means that there is a statistically significant between passengers' perspective and comfortability of the airline services. Also, there is a positively significant relationship between passenger satisfaction and perceived comfortability of service of the airline since $p<0.05$. This implies that the higher perceived comfort of service, the higher in passenger satisfaction. Wanke et al., (2016) state that service comfortability is the measurement of how passengers regard the quality of service provided by the airlines; Internet connectivity, lounge's cleanliness, and business pavilion. Interactive and physical qualities are considered to be the tangible features of airline service by the passengers (Chen et al.,2005). 
Table 4.12

Coefficient of Independent Variables for Comfortability Analysis Coefficients ${ }^{a}$

\begin{tabular}{|c|c|c|c|c|c|}
\hline \multirow[t]{2}{*}{ Model } & \multicolumn{2}{|c|}{$\begin{array}{l}\text { Unstandardized } \\
\text { Coefficients }\end{array}$} & \multicolumn{2}{|c|}{$\begin{array}{l}\text { Standardized T } \\
\text { Coefficients }\end{array}$} & \multirow[t]{2}{*}{ Sig. } \\
\hline & & & & & \\
\hline (Constant) & -.056 & .408 & & -.137 & .891 \\
\hline Flight schedule & .000 & .097 & .000 & .002 & .999 \\
\hline Amount paid & .009 & .030 & .014 & .305 & .761 \\
\hline Flight delay & .509 & .188 & .275 & 2.707 & .008 \\
\hline Freq of flight delay & -.053 & .030 & -.182 & -1.793 & .075 \\
\hline Security service & .100 & .057 & .097 & 1.743 & .084 \\
\hline Safety challenges & -.234 & .355 & -.112 & -.659 & .511 \\
\hline $\begin{array}{l}\text { Freq of safety } \\
\text { challenge }\end{array}$ & .046 & .046 & .168 & .988 & .325 \\
\hline Airline innovation & .074 & .039 & .099 & 1.916 & .058 \\
\hline Quality of service & .713 & .058 & .770 & 12.193 & .000 \\
\hline
\end{tabular}

a. Dependent Variable: Comfortability

Table 4.12 shows the extent to which all the dependent variables are related to the independent variable. The model coefficient of nine variables are: $\mathrm{Y}=-.056+$ $(.000) \mathrm{x}_{1}+(.009) \mathrm{x}_{2}+(.509) \mathrm{x}_{3}+(-.053) \mathrm{x}_{4}+(.100) \mathrm{x}_{5}+(-.234) \mathrm{x}_{6}+(.046) \mathrm{x}_{7}+(.074)$ $\mathrm{x}_{8}+(.713) \mathrm{x}_{9}$

Table 4.13

Analysis of Variance for Comfortability Analysis ANOVA ${ }^{a}$

\begin{tabular}{|llccccc|}
\hline & Model & Sum of Squares & $d f$ & Mean Square & $F$ & Sig. \\
\hline \multirow{4}{*}{1} & Regression & 87.582 & 9 & 9.731 & 52.378 & $.000^{\mathrm{b}}$ \\
Residual & 22.295 & 120 & .186 & & \\
Total & 109.877 & 129 & & & \\
\hline
\end{tabular}

Table 4.14

Regression Analysis for Affordability Model Summary

\begin{tabular}{|ccccc|}
\hline Model & $R$ & $R$ Square & Adjusted $R$ Square & $\begin{array}{c}\text { Std. Error of the } \\
\text { Estimate }\end{array}$ \\
\hline 1 & $.817^{\mathrm{a}}$ & .667 & .642 & .433 \\
\hline
\end{tabular}

a. Predictors: (Constant), Quality of service, Flight delay, Safety challenges, Amount paid, Flight schedule, Airline innovation, Security service, Frequency of flight delay, Frequency of safety challenge. 
The regression analysis of the relationship between $\mathrm{A}(\mathrm{y})$ - (Affordability as the dependent variable) and $\mathrm{QS}\left(\mathrm{x}_{1}\right)$ - (quality of service ), $\mathrm{FD}\left(\mathrm{x}_{2}\right)$ - (flight delay), $\mathrm{SC}\left(\mathrm{x}_{3}\right)$ - (safety challenges), $\mathrm{AP}\left(\mathrm{x}_{4}\right)$ - (amount paid), $\mathrm{FS}\left(\mathrm{x}_{5}\right)$ - (flight schedule), $\mathrm{AI}\left(\mathrm{x}_{6}\right)$ - (airline innovation), $\mathrm{SS}\left(\mathrm{x}_{7}\right)$ - (security service), $\mathrm{FFD}\left(\mathrm{x}_{8}\right)$ - (frequency of flight delay), $\mathrm{FSC}\left(\mathrm{x}_{9}\right)$ - (frequency of safety challenge), as the independent variable of the quality of service of airline operation in Kano airport was analysed.

In analyzing the data, the summary output of the spreadsheet show the Rsquare value of 0.667 , which means that about $67 \%$ of passenger response on the affordability of service in the airline operation at the airport was above average which means that there is an average relationship between the explained variable and the explanatory variables $\left(\mathrm{x}_{1}, \mathrm{x}_{2}, \mathrm{x}_{3}, \mathrm{x}_{4}, \mathrm{x}_{5}, \mathrm{x}_{6}, \mathrm{x}_{7}, \mathrm{x}_{8}\right.$ and $\left.\mathrm{x}_{9}\right)$ respectively. The adjusted $\mathrm{R}$ was 0.642 which means that about $64 \%$ of the affordability explained by the explanatory variables. This value is also reasonable and close to the R-square valve. Finally, the overall relationship of the analysis for affordability from the customers' perspective as the dependent variable (Y) and the independent or explanatory variable $\left(\mathrm{x}_{1}, \mathrm{x}_{2}, \mathrm{x}_{3}, \mathrm{x}_{4}, \mathrm{x}_{5}, \mathrm{x}_{6}, \mathrm{x}_{7}, \mathrm{x}_{8}\right.$ and $\left.\mathrm{x}_{9}\right)$ is about 0.817 , which is about $82 \%$ (multiple $\mathrm{R}$ ) and this is a strong relationship.

Table 4.15

Coefficient of Independent Variables for Affordability Analysis Coefficients ${ }^{a}$

\begin{tabular}{|c|c|c|c|c|c|c|}
\hline \multirow{2}{*}{\multicolumn{2}{|c|}{ Model }} & \multicolumn{2}{|c|}{$\begin{array}{l}\text { Unstandardized } \\
\text { Coefficients }\end{array}$} & \multirow{2}{*}{$\begin{array}{c}\text { Standardized } \\
\text { Coefficients } \\
\text { Beta }\end{array}$} & \multirow[t]{2}{*}{$T$} & \multirow[t]{2}{*}{ Sig. } \\
\hline & & $B$ & Std. Error & & & \\
\hline \multirow{10}{*}{1} & (Constant) & 1.316 & .410 & & 3.211 & .002 \\
\hline & Flight schedule & -.237 & .098 & -.143 & -2.421 & .017 \\
\hline & Amount paid & .019 & .030 & .038 & .638 & .525 \\
\hline & Flight delay & .054 & .189 & .037 & .285 & .776 \\
\hline & Freq of flight delay & -.016 & .030 & -.068 & -.526 & .600 \\
\hline & Security service & -.344 & .058 & -.427 & -5.960 & .000 \\
\hline & Safety challenges & -.497 & .357 & -.303 & -1.393 & .166 \\
\hline & $\begin{array}{l}\text { Freq of safety } \\
\text { challenge }\end{array}$ & .050 & .047 & .232 & 1.069 & .287 \\
\hline & Airline innovation & .147 & .039 & .251 & 3.774 & .000 \\
\hline & Quality of service & .589 & .059 & .810 & 10.012 & .000 \\
\hline
\end{tabular}

a. Dependent Variable: Affordability

Table 4.15 shows the extent to which all the dependent variables are related to the independent variable. The model coefficient of the nine variables are: $\mathrm{Y}=$ $1.316+(-.237) \mathrm{x}_{1}+(.019) \mathrm{x}_{2}+(.054) \mathrm{x}_{3}+(-.016) \mathrm{x}_{4}+(-.344) \mathrm{x}_{5}+(-.497) \mathrm{x}_{6}+(.050)$ $\mathrm{x}_{7}+(.147) \mathrm{x}_{8}+(.589) \mathrm{x}_{9}$. 
Table 4.16

Analysis of Variance for Affordability Analysis ANOVA ${ }^{a}$

\begin{tabular}{|llccccc|}
\hline Model & & $\begin{array}{c}\text { Sum of } \\
\text { Squares }\end{array}$ & $d f$ & Mean Square & $F$ & Sig. \\
\hline 1 & Regression & 45.163 & 9 & 5.018 & 26.720 & $.000^{\mathrm{b}}$ \\
& Residual & 22.537 & 120 & .188 & & \\
\hline & Total & 67.700 & 129 & & & \\
\hline
\end{tabular}

a. Dependent Variable: Affordability

b. Predictors: (Constant), Quality of service, Flight delay, Safety challenges, Amount paid, Flight schedule, Airline innovation, Security service, Frequency of flight delay, Frequency of safety challenge.

H2: There is no statistically significant relationship between passenger's perspectives and affordability of service in the airline's operation at the airport. Table 4.16, shows that the F value of 129, degree of freedom 26.720 and the tabulated value is 0.00 so therefore alternative hypothesis is accepted since the tabulated is less than p-value 0.05 , which means there is a statistically significant relationship between passengers' perspectives and affordability of services. Also, there is positively significant relationship between passenger satisfaction and perceived affordability of service by the airline since $p<0.05$. This implies that the higher the perceived affordability of service, the higher passenger satisfaction. This means that more passengers will be attracted to use these airlines, thus giving them compactivities edge over their competitors in the sector. Providing passengers with different ticket prices, which they can afford is a gesture of goodwill on the part of airline companies, as this can encourage and promote customer loyalty and repeat purchase (Benjamin, 2015). As the price of air tickets continues to drop in the continent, more passengers will be able to afford traveling by air in the future (Benjamin, 2015). Therefore, an affordable ticket price will encourage more people to use these airlines.

Table 4.17

Regression Analysis for Reliability Model Summary

\begin{tabular}{|c|c|c|c|c|}
\hline Model $\mathrm{K}$ & $\mathrm{R}$ & R Square & $\begin{array}{l}\text { Adjusted } \\
\text { Square }\end{array}$ & $\begin{array}{l}\text { RStd. Error of the } \\
\text { Estimate }\end{array}$ \\
\hline 1 & $.773^{\mathrm{a}}$ & .597 & .567 & .523 \\
\hline
\end{tabular}

Predictors: (Constant), Quality of service, Flight delay, Safety challenges, Amount paid, Flight schedule, Airline innovation, Security service, Frequency of flight delay, Frequency of safety challenge. 
The regression analysis of the relationship between $\mathrm{R}(\mathrm{y})-($ Reliability as the dependent variable ) and $\mathrm{QS}\left(\mathrm{x}_{1}\right)$ - ( quality of service ), $\mathrm{FD}\left(\mathrm{x}_{2}\right)$ - ( flight delay), $\mathrm{SC}\left(\mathrm{x}_{3}\right)$ - (safety challenges), $\mathrm{AP}\left(\mathrm{x}_{4}\right)$ - (amount paid), $\mathrm{FS}\left(\mathrm{x}_{5}\right)$ - (flight schedule), $\mathrm{AI}\left(\mathrm{x}_{6}\right)$ - (airline innovation), $\mathrm{SS}\left(\mathrm{x}_{7}\right)$ - (security service), $\operatorname{FFD}\left(\mathrm{x}_{8}\right)$ (frequency of flight delay), $\mathrm{FSC}\left(\mathrm{x}_{9}\right)$ - (frequency of safety challenge), as the independent variable of the quality of service of airline operations in Kano airport was analysed. In analyzing the data, the summary output of the spreadsheet shows the R-square value of 0.597 , which means that about $60 \%$ of passenger response on reliability of service to the airline operation of the airport was above the average which means that there is average relationship between the explained and the explanatory variables $\left(\mathrm{x}_{1}, \mathrm{x}_{2}, \mathrm{x}_{3}, \mathrm{x}_{4}, \mathrm{x}_{5}, \mathrm{x}_{6}, \mathrm{x}_{7}, \mathrm{x}_{8}\right.$, and $\left.\mathrm{x}_{9}\right)$ respectively. The adjusted $\mathrm{R}$ of 0.567 which is about $57 \%$ is just on the average, and it is not strong. The reliability explained by the explanatory variables. This value is not very reasonable, and although it is close to the R-square value. Finally, the summary shows the overall relationship to the analysis of passenger perspectives on the reliability of service. The relationship between dependent variable (Y) and the independent or explanatory variable $\left(\mathrm{x}_{1}, \mathrm{x}_{2}, \mathrm{x}_{3}, \mathrm{x}_{4}, \mathrm{x}_{5}, \mathrm{x}_{6}, \mathrm{x}_{7}, \mathrm{x}_{8}\right.$ and $\left.\mathrm{x}_{9}\right)$ is 0.773 , which is about $77 \%$ (multiple $\mathrm{R}$ ) and this is a strong relationship.

Table 4.18

Coefficient of Independent Variables for Reliability Analysis Coefficients ${ }^{a}$

\begin{tabular}{|c|c|c|c|c|c|}
\hline \multirow[t]{2}{*}{ Model } & \multicolumn{2}{|c|}{$\begin{array}{l}\text { Unstandardized } \\
\text { Coefficients }\end{array}$} & \multirow{2}{*}{$\begin{array}{c}\text { Standardized } \\
\text { Coefficients } \\
\text { Beta }\end{array}$} & \multirow[t]{2}{*}{$T$} & \multirow[t]{2}{*}{ Sig. } \\
\hline & $B$ & Std. Error & & & \\
\hline (Constant) & .333 & .495 & & .672 & .503 \\
\hline Flight schedule & -.389 & .118 & -.214 & -3.298 & .001 \\
\hline Amount paid & .039 & .037 & .068 & 1.052 & .295 \\
\hline Flight delay & .212 & .228 & .133 & .931 & .354 \\
\hline Freq of flight delay & -.056 & .036 & -.220 & -1.546 & .125 \\
\hline Security service & -.105 & .070 & -.118 & -1.503 & .135 \\
\hline Safety challenges & .287 & .431 & .159 & .666 & .506 \\
\hline $\begin{array}{l}\text { Freq of safety } \\
\text { challenge }\end{array}$ & -.036 & .056 & -.154 & -.645 & .520 \\
\hline Airline innovation & .070 & .047 & .108 & 1.479 & .142 \\
\hline Quality of service & .655 & .071 & .821 & 9.230 & .000 \\
\hline
\end{tabular}

a. Dependent Variable: Reliability

Table 4.18 shows the extent to which all the dependent variables are related to the independent variable. The model coefficients of the nine variables are: 
$\mathrm{Y}=.333+(-.389) \mathrm{x}_{1}+(.039) \mathrm{x}_{2}+(.212) \mathrm{x}_{3}+(-.056) \mathrm{x}_{4}+(-.105) \mathrm{x}_{5}+(.287) \mathrm{x}_{6}+(-$ $.036) \mathrm{x}_{7}+(.070) \mathrm{x}_{8}+(.655) \mathrm{x}_{9}$

Table 4.19

Analysis of Variance for Reliability Analysis ANOVA ${ }^{a}$

\begin{tabular}{|llccccc|}
\hline Model & & $\begin{array}{c}\text { Sum of } \\
\text { Squares }\end{array}$ & $d f$ & Mean Square & $F$ & Sig. \\
\hline \multirow{2}{*}{1} & Regression & 48.716 & 9 & 5.413 & 19.767 & $.000^{\mathrm{b}}$ \\
\hline & Residual & 32.861 & 120 & .274 & & \\
\hline
\end{tabular}

a. Dependent Variable: Reliability

b. Predictors: (Constant), Quality of service, Flight delay, Safety challenges, Amount paid Flight schedule, Airline innovation, Security service, Frequency of flight delay, Frequency of safety challenge.

H3: There is no statistically significant relationship between passengers' perspectives and reliability of service in the airline's operation at this airport.

Table 4.19, shows that the $\mathrm{F}$ value of 129 degrees of freedom is 19.767 and the tabulated value is 0.00 , so therefore alternative hypothesis is accepted since the tabulated value is less than p-value 0.05 , which means that there is a statistically significant relationship between passengers' perspectives and reliability of the airline services. In addition, there is a positively significant relationship between passenger satisfaction and perceived reliability of service of the airline since $(p<0.05)$. This suggests that the higher in perceived service reliability, the higher in passenger satisfaction. As Parasuraman, Zeithaml, and Berry (1985) noted, customers expect their services to be on time, as scheduled on the flight timetable. The airline industry is duty-bound to carry passengers from destination A to B, without any delay and cancellation.

\section{Conclusion and Recommendations}

The study findings revealed that independent variables influenced airline's quality of service at the KAN. The outcome of service quality analysis demonstrated that there is a statistically significant relationship between passengers' perspectives and reliability of the airline services. Secondly, there is a statistically significant relationship between passengers' perspectives and affordability of services. Finally, there is a statistically significant link between passenger's perspectives and comfortability of the airline services. Based on the study findings the authors recommended that airline's service reliability needs to improve to meet passenger demands and expectations, as this variable was rated average in these airlines. 
International Journal of Aviation, Aeronautics, and Aerospace, Vol. 4 [2017], Iss. 1, Art. 7

Airlines should also develop and maintain passenger oriented marketing strategies to improve affordability and repeat patronage. Lastly, the Government should create industry- specific policy to encourage and support direct investment in the sector which brings passenger comfort. 


\section{References}

Benjamin, R. (2015). Global aviation and our sustainable future. ICAO International Civil Aviation Organization Briefing for RIO+20. Retrieved from http://www.icao.int/environmentalprotection/Documents/RIO+20_booklet.pdf

Chang, Y.H., \& Yeh, C. H. (2002). A Survey analysis of service quality for domestic airlines, European Journal of Operational Research, 193, 166177. doi: http://dx.doi.org/10.1016/S0377-2217(01)00148-5

Chen, F., \& Chang, Y. (2005). Examining airline service quality from a process perspective. Journal of Air Transport Management, 11, 79- 87. doi: http://dx.doi.10.1016/j.jairtraman.2004.09.002

Chen, C. F. (2008). Investigating structural relationships between service quality, perceived value, and customer satisfaction on customer behavioral intentions for air passengers: Evidence from Taiwan. Transportation Research Part A, 42, 709-177. doi: http://dx.doi:10.1016/j.tra.2008.01.007

Chou, C. C., Liu, L. J., Huang, S. F., Yih., J. M. \& Han, T. C. (2011). An evaluation of airline service quality using the fuzzy weighted SERVQUAL method, Applied Soft Computing, 11, 2117-2128. doi: http://dx.doi.org/10.1016/j.asoc.2010.07.010.

Cronin, J.J., \& Taylor, S.A. (2011). Measuring service quality: A reexamination and extension. Journal of Marketing, 56(3), 55-68. doi: http://dx.doi.org/10.2307/1252296.

Erdil, S., \& Yildiz, O. (2011). Measuring service quality and comparative analysis in the passenger carriage of airline industry, Procedia Social and Behavioral Science, 24, 1232-1242. doi: http://dx.doi.org/10.1016/j.sbspro.2011.09.117

Federal Aviation Administration. (2016). Home page. Retrieved from www.faa.com

Fernandes, E., \& Pacheco, R. R. (2010). A quality approach to airport management. Qual Quant, 44, 551-564. doi: http://dx.doi.org/10.1007/s11135-008-9212-9 
Garvin, G (2010). What does “product quality” really mean? Sloan Management Review, 26(1), 25-43.

Geraldine, O., \& David, U.C. (2013). Effects of airline service quality on airline image and passengers' loyalty: Findings from Arik Air Nigeria passengers. Journal of Hospitality and Management Tourism, 4(2), 19-28. doi: http://dx.doi :10.5897/JHMT2013.0089

Griffin, J. (2008). Customer loyalty. New York: Lexington Book.

Lubbe, B., Douglas, A., \& Zambellis, J. (2011). An application of the airport service quality model in South Africa, Journal of Air Transport Management, 17, 224-227. doi: http://dx.doi.org/10.1016/j.jairtraman.2010.08.001

Lopes, I, \& Rodrigues, A. M. G. (2007). Intangible assets identification and valuation a theoretical framework approach to the Portuguese airlines companies, The Electronic Journal of Knowledge Management, 5(2), 193202. doi: http://dx.doi.org/10.1016/j.sbspro.2013.12.884

Nwaogbe, O. R., Wokili, H., Omoke, V., Asiegbu, B. (2013). An Analysis of the impact of air transport sector to economic development in Nigeria, IOSR Journal of Business Management, 14(5), 41- 48. doi: http://dx.doi.org/10.9790/487X-1454148

Parasuraman, A.A., Zeithaml, V.A., \& Berry, L.L. (1985). A Conceptual Model of Service Quality and Its Implications for Future Research. Journal of Marketing. 49(4), 41-50. doi: http://dx.doi.org/10.2307/1251430

Park, J.W., Robertson, R, \& Wu, C. (2004). The effect of airline service quality on passengers' behavioral intentions: A Korean case study. Journal of air Transport Management, 10, 435-439. doi: http://dx.doi:10.1016/j.jairtraman.2004.06.001

Preacher, K. J., \& Hayes, A. F. (2008). Asymptotic and resampling strategies for assessing and comparing indirect effects in multiple mediator models. Behavior Research Methods, 40, 879-891.

Rhoades, D., \& Waguespack B. (2004). Service and safety quality in US airlines: pre- and post-September $11^{\text {th }}$. Managing Service Quality, 14(4), 307-316. doi: http://dx.doi.10.1108/09604520410546842 
Rhoades, D., \& Waguespack B. (2008). Twenty years of service quality performance in the US airline industry. Managing Service Quality, 18(1), 20-33. doi: http://dx.doi.10.1108/09604520810842821

Suki, N. M. (2014). Passenger satisfaction with airline service quality in Malaysia: A structural equation modeling approach. Research in Transportation Business \& Management, 10. doi: http://dx.doi.org/10.1016/j.rtbm.2014.04.001

Wanke, P., Barros, C. P., \& Nwaogbe, O. R. (2016). Assessing productive efficiency in Nigerian airports using Fuzzy-DEA, Transport Policy, 49, 9-19. doi: http://dx.doi.org/10.1016/j.tranpol.2016.03.012

Wahab, Z., Sukati, I., \& Hua Li, L. (2015). Measuring the Malindo Airline passenger's satisfaction. Canadian Center of Science and Education, 11 (18). doi: http://dx.doi:10.5539/ass.v11n18p233

Yayla-Kullu, H. M., \& Tansitpong, P. (2013). A Critical Evaluation of U.S. Airlines' Service Quality Performance: Lower Costs vs. Satisfied Customers. Journal of Management and Strategy, 4(4). doi: http://dx.doi.org/10.5430/jms.v4n4p1.

Zhang, B., Wang, J., Liu, C \& Zhao, Y. (2012). Evaluating the technical efficiency of Chines airport airside activities, Journal of Air Transport Management, 20, 23-27 doi: http://dx.doi.org/10.1016/j.jairtraman.2011.10.007 